\title{
ROZWÓJ KONCEPCJI INTEGRACJI PRODUKTOWO- -USEUGOWEJ (PRODUCT-SERVICE SYSTEMS)
}

\begin{abstract}
W obecnych czasach granica między sektorem usługowym a produkcyjnym stała się rozmyta, a czasem wręcz niezauważalna. Zarówno przedsiębiorstwa typowo usługowe, jak i produkcyjne, zainteresowane są rozszerzaniem swojej oferty, tak by w sposób kompleksowy zaspokajać potrzeby swoich klientów. $Z$ drugiej zaś strony warunki silnej konkurencji wymuszają na przedsiębiorcach wprowadzanie innowacji i wzbogacanie ofert w celu nawiązania długich i pozytywnych relacji z klientami, partnerami i dostawcami. Koncepcja integrowania produktów (wyrobów fizycznych) i usług, jako rozwiązania systemowego oferowanego klientom w formie kompleksowej oferty zorientowanej na jej funkcjonalność czy też rezultat, jest stosunkowo nowym obszarem w badaniach naukowych, wciąż gorąco i chętnie dyskutowanym w środowiskach akademickich na całym świecie. Zintegrowana oferta pozwala na zaspokojenie takich potrzeb klienta, których wyrób ani usługa osobno nie są w stanie zaspokoić na określonym poziomie satysfakcji. Włączanie usług w sektorze przemysłu wpisuje się $\mathrm{w}$ nurt zrównoważonego rozwoju poprzez przesunięcie koncentracji przedsiębiorstw wytwórczych na obrót wartością niematerialną, czyli usługą zorientowana na produkt materialny, jego funkcjonalność lub użyteczność czy też dostępność. W artykule dokonano przeglądu publikacji naukowych pod kątem rozwoju koncepcji integracji produktowousługowej (najczęściej określaną w literaturze zagranicznej pojęciem systemu produktowousługowego, czyli product-service system) oraz zidentyfikowano kierunki badań podejmowanych w tym obszarze. Analiza wybranych pozycji literaturowych pozwoliła na wskazanie problemów badawczych i pytań, które stanowią wyzwanie dla środowiska nauki na przyszłość.
\end{abstract}

Slowa kluczowe: integracja produktowo-usługowa, serwicyzacja, system produktowo-usługowy, przegląd literatury, eksploracja tekstu (text mining).

\section{WPROWADZENIE}

W ostatnich latach XX wieku, sektor usług stał się wiodącym w większości gospodarek na świecie. Według raportu GUS w 2014 roku wartość dodana pochodzaca z tego sektora stanowiła od 60\% (w Polsce 64\%) do niemal 90\% (Luksemburg - 88\%, Cypr $87 \%$ ) wartości dodanej wytworzonej w całej gospodarce danego kraju². Rosnąca siła wpływu klientów na decyzje podejmowane przez przedsiębiorstwa spowodowała, iż nawet w sektorach związanych $\mathrm{z}$ tradycyjną produkcją usługi zyskały na znaczeniu, czasem stając się podstawą oferty rynkowej wytwórcy. Zjawisko to, nazywane w literaturze ser-

\footnotetext{
${ }^{1}$ Mgr Justyna Kozłowska, Wydział Zarządzania, Politechnika Białostocka, Białystok, ul. Wiejska 45A, 15-351 Białystok, e-mail: j.kozlowska@pb.edu.pl, tel. 85 746-98-80. Badania zostały zrealizowane w ramach pracy statutowej S/WZ/1/2014 i sfinansowane ze środków na naukę MNiSW.

2 Rynek wewnętrzny w $2014 \mathrm{r}$., raport Głównego Urzędu Statystycznego, http://stat.gov.pl/obszarytematyczne/ceny-handel/handel/rynek-wewnetrzny-w-2014-r-,7,20.html (dostęp: 25.04.2016 r.).
} 
wicyzacją, stało się w XXI wieku faktem i trudno dyskutować z poglądem, iż gospodarka światowa oparta jest na usługach ${ }^{3}$, a funkcjonalność produktu czy też jego dostępność jest zarówno z punktu widzenia ekonomii, ekologii, jak i klienta rozwiązaniem korzystniejszym i pożądanym ${ }^{4}$. Efektem tych przemian jest przesunięcie orientacji gospodarek większości krajów wysoko rozwiniętych oraz rozwijających się w kierunku usług czy też, innymi słowy, gospodarki funkcjonalnej, gdzie przedmiotem obrotu jest użyteczność lub funkcjonalność wytworzonego produktu materialnego lub też usługi. W sektorze przemysłu włączanie usług w oferte przedsiębiorstwa powoduje efektywniejsze wykorzystanie produktów wytworzonych poprzez optymalniejsze parametry zużycia materiałów i energii w całym cyklu życia produktu ${ }^{5}$. $Z$ drugiej zaś strony przedsiębiorstwa usługowe w walce o lojalnego klienta rozszerzają swoje oferty o produkty (wytworzone samodzielnie bądź we współpracy z producentem) dostarczając odbiorcy kompleksowe rozwiązania zaspokajające jego potrzeby, zatem również i w sektorze usługowym funkcjonują modele biznesowe oparte o integrację usługi z produktem materialnym. Coraz trudniej jednoznacznie rozdzielić sektor usługowy od przemysłowego lub przyporządkować działalność przedsiębiorstwa do jednego z nich. Granica między świadczeniem usług a produkcją wyrobów materialnych zaciera się i znaczny udział w tym procesie ma stosowanie przez przedsiębiorców kombinacji usług z produktami fizycznymi.

Obszar badawczy dotyczący integracji produktów z usługami, czy też, tłumacząc bezpośrednio najczęściej pojawiające się obecnie pojęcie związane $\mathrm{z}$ oferowaniem tego typu rozwiązań, systemów produktowo-usługowych (ang. product-service system), gdzie produkt jest namacalnym elementem oferowanego rozwiązania, usługa zaś jest jego komponentem niematerialnym, narodził się i początkowo rozwijał w ramach koncepcji zrównoważonego rozwoju ekonomicznego, z którą wiązały się postulaty produkcji zrównoważonej dla przemysłu, tj. takiej, której negatywny wpływ na środowisko będzie ograniczany, zaś satysfakcja klienta będzie poprzez świadczone mu usługi maksymalizowana ${ }^{6}$. Z uwagi na różnorodność terminów oraz definicji związanych z analizowanym obszarem, na po-

| trzeby niniejszych rozważań przyjęto definicję integracji produktowo-usługowej rozumianej jako łączenie w sposób integralny wyrobów fizycznych oraz niematerialnych usług $\mathrm{w}$ jedno rozwiązanie oferowane klientom zapewniające zaspokojenie takich ich potrzeb, których wyrób ani usługa osobno nie są w stanie zaspokoić na określonym poziomie satysfakcji, przy czym stosunek udziałów poszczególnych komponentów rozwiązania (produktu fizycznego i usługi) mogą różnić się w zależności od wymagań czy też ze względów ekonomicznych.

Poniższe opracowanie ma charakter przeglądowy. $\mathrm{Z}$ uwagi na znikomą liczbę publikacji polskich ${ }^{7}$ skupiono się na literaturze zagranicznej.

${ }^{3}$ E. Szymańska, Serwicyzacja gospodarki jako źródto jej transformacji, „Optimum. Studia Ekonomiczne" 2015, nr 1 (73), s. 97-109.

${ }^{4}$ C. Vezzoli, C. Kohtala, A., Srinivasan, Product-Service System Design for Sustainability, Sheffield: Greenleaf Publishing Limited, 2014, p. 31.

${ }_{5}$ J. Kronenberg, T. Bergier (red.), Wyzwania zrównoważonego rozwoju w Polsce, Kraków 2010, s. 201.

${ }^{6}$ A. Tukker, Product services for a resource-efficient and circular economy - a review, "Journal of Cleaner Production" 2015, vol. 97, p. 76-91.

${ }^{7}$ Zob. P. Brzustewicz, Systemy produktowo-ushugowe jako sposób realizacji rozwoju zrównoważonego w biznesie, „Marketing i Rynek” 2012, nr 10, s. 23-27; J. Janczewski, Systemy produktowo-ustugowe w transporcie - wybrane przykłady, „Zarządzanie Innowacyjne w Gospodarce

Usunięto: ,

Usunięto: Tomasz 


\section{NARODZINY KONCEPCJI INTEGRACJI USLUG I PRODUKTÓW MATERIALNYCH}

Rosnący poziom konsumpcji w ostatnich dekadach XX wieku, a także przyrost populacji globalnej i wzrost produkcji pociągnęły za sobą intensywny wzrost zużycia zasobów, zarówno tych naturalnych ( $\mathrm{tj}$. woda, ziemia, zasoby mineralne), jak i wytwarzanych przez człowieka (energia czy produkcja rolna), co z kolei stało się tematem dyskusji i problemem, dla którego satysfakcjonujących rozwiązań poszukiwać zaczęto w środowiskach naukowych, ekonomicznych czy politycznych, na szczeblu krajowym oraz globalnym. Koncepcja zrównoważonego rozwoju, czyli takiego wzrostu gospodarczego, który pozwoli ograniczać szkodliwy wpływ produkcji i konsumpcji na stan środowiska naturalnego, znalazła się w polu zainteresowania wielu organizacji międzynarodowych (UNEP, UNDP, UE), a także odnalazła swoje odzwierciedlenie w systemie prawa międzynarodowego (Agenda 21, Karta Lipska). W tym duchu również narodziła się idea „dematerializowania" ekonomii - czyli redukcji zużycia i przepływu materiałów w procesach produkcji i konsumpcji poprzez dostarczanie konsumentom rozwiązań/usług opartych na użyteczności czy funkcjonalności produktów, czego efektem ubocznym byłaby redukcja negatywnego wpływu na środowisko naturalne ${ }^{8}$. Już na przełomie wieków XX i XXI w. krajach skupionych w OECD sektor usługowy zatrudniał ok. 64\% wszystkich pracują$\mathrm{cych}^{9}$, a trend ten nadal wykazuje tendencję rosnącą. W 2014 roku wartość dodana wytworzona przez sektor usługowy w niektórych krajach sięgała nawet 87\% (Cypr) wartości dodanej wytworzonej przez całą gospodarkę danego kraju, a w większości krajów rozwiniętych stanowi ona ponad $50 \%$ tejże wartości ${ }^{10}$. Niematerialna wartość, którą niosą za sobą usługi, stała się przedmiotem obrotu również w sektorach zorientowanych na produkcję. Usługi, jako dodatek do sprzedawanych wyrobów, zazwyczaj postrzegane są jako mniej szkodliwe dla otoczenia i środowiska naturalnego niż masowa produkcja i niekontrolowana konsumpcja, i jednocześnie niosące możliwości tworzenia wartości dodanej dla nabywcy, dywersyfikowania ofert i osiągania korzyści zarówno ekonomicznych (np. poprzez poprawę produktywności i efektywne wykorzystanie materiałów i zasobów) jak i ekologicznych (np. poprzez przedłużanie cyklu życia produktów materialnych i kontrolę nad ich utylizacją). Według Tukkera, Walther Stahel w 1982 roku oraz Friedrich SchmidtBleek w 1993 jako pierwsi wskazali korzyści zastosowania modeli biznesowych opartych na integracji usług i produktów materialnych ${ }^{11}$. Stahel był tym, który przedstawił koncepcję „service society” (społeczeństwo usługowe) i „service economy” (gospodarka usługowa) jako sposób na zapewnienie zrównoważonego rozwoju w gospodarce. Gospodarka usługowa, często łączona z pojęciem gospodarki funkcjonalnej, opiera się na obrocie wartościami niematerialnymi, czyli w przypadku produktów fizycznych centralną warto-

_i Biznesie" 2014, nr 1 (18), s. 51-61; J. Janczewski, Wynajem jako forma wspótużytkowania __samochodów: wybrane kwestie, „Zarządzanie Innowacyjne w Gospodarce i Biznesie” 2015, nr 2 — (21), s. 86-101; J. Kozłowska, Product-Service System in a manufaturing company strategy-s review paper, „Ekonomia i Zarządzanie” 2015, vol, 7, p. 48-56.

${ }^{8} \mathrm{O}$. Mont, Clarifying the concept of product-service system, "Journal of Cleaner Production" 2002, Vol. 10 (3), p. 237-245.

${ }^{9}$ OECD 2000. The service economy, dokument elektroniczny, https://www.oecd.org/sti/ind/ 2090561.pdf, (dostęp: 01.05.2016 r.).

${ }^{10}$ E. Szymańska, Serwicyzacja gospodarki..

11 A. Tukker, Product services for a resource-efficient...

\begin{tabular}{|l|}
\hline Usunięto: - \\
\hline Usunięto: \\
\hline Usunięto: \\
\hline
\end{tabular}


ścią obrotu jest usługa zorientowana na produkt, funkcjonalność albo użyteczność produktu lub też jego dostępność. Sam produkt zaś traktuje się raczej jako nakład kapitału niż dobro konsumpcyjne. W gospodarce funkcjonalnej konsument nie kupuje samochodu lecz możliwość odbycia podróży; nie nabywa pralki ani detergentów lecz usługę prania/czyszczenia; nie zaopatruje się w meble biurowe lecz je wypożycza ${ }^{12}$. A zatem, jak zauważa Stahel, w takim modelu gospodarki optymalizuje się użyteczność (funkcjonalność) produktów i usług, a tym samym zarządzanie dostępnymi zasobami (materialnymi, niematerialnymi np. wiedzą czy naturalnymi), zaś celem ekonomicznym jest wytworzenie wartości użytkowej w możliwie najdłuższym czasie zużywając przy tym możliwie najmniejszą ilość zasobów i energii ${ }^{13}$.

Na tle wspomnianych koncepcji narodziła się idea kombinacji produktów i usług, a w zasadzie potrzeba ich badania, rozwijania i szukania optymalnych dla wszystkich interesariuszy (klient/nabywca, użytkownik, dostawca, producent, urzędnik) rozwiązań, gdyż produkt kombinowany, czy też usługa najmu dóbr o wysokiej wartości funkcjonowała na rynku od dawna (wypożyczanie książek, najem lokali). Dobra materialne zazwyczaj stanowiły centralną część tych kombinacji i skupiały uwagę zarówno klienta, dostawcy usługi, jak i producenta, zatem metody i narzędzia projektowania, usprawniania i zarządzania dotyczyły głównie tylko produktu fizycznego. Produkcja wyrobów materialnych i działalność usługowa, mimo iż spotykały się nierozerwalnie na pewnym etapie cyklu życia produktu, traktowane i rozważane były osobno. Koncepcja tworzenia i dostarczania kompleksowych rozwiązań kombinowanych podkreśla zmianę podejścia zorientowanego dotychczas na produkt lub usługę na podejście systemowe, uwzględniające na każdym etapie cyklu życia produktu i usługi ich integrację i nierozerwalność; wymaga postrzegania dostarczanego rozwiązania jako systemu powiązanych ze sobą ściśle elementów ${ }^{14}$. A zatem wszystkie etapy zarządzania zintegrowanymi rozwiązaniami produktowo-usługowymi, począwszy od analiz wstępnych, poprzez etap użytkowania, usprawniania, aż po działania podejmowane po zakończeniu cyklu życia produktu i usługi, muszą dotyczyć wszystkich komponentów łącznie, z uwzględnieniem stron (partnerzy, dostawcy, odbiorcy usług, klienci) pojawiających się w procesie dostarczania tegoż rozwiązania. Rysunek 1 przedstawia ewolucję koncepcji łączenia produktów i usług w rozwiązania systemowe.

Problematyczną kwestią było, i nadal jest, definiowanie rozwiązań systemowych w sposób jednoznaczny. Analizując literaturę tematu zauważyć można różnorodność zarówno w nazewnictwie, jak i w definiowaniu pojęcia integracji produktowo-usługowej. Najczęściej jednak pojawiającym się od kilkunastu lat terminem jest product-service system (PSS) i jego odmiany (product/service system, product service system, industrial product-service system). Pierwszą definicję PSS zaproponował w 1999 roku holenderski zespół badaczy (Goedkoop, van Halen, te Riele, Rommers) uściślając na wstępie wszystkie terminy pojawiające się $\mathrm{w}$ ostatecznym pojęciu systemu produktowo-usługowego. A zatem produktem określają oni dobro materialne, które można zbyć. Jest to rzecz, która

${ }^{12} \mathrm{O}$. Mont, Clarifying the concept ...

| ${ }^{13}$ W.R. Stahel, The functional economy: cultural and organizational change [w:] The industrial green game: implications for environmental design and management, Waszyngton 1997, p. $91-100$.

14 S. Cavalieri, G. Pezzotta, Product-Service Systems Engineering:State of the art and research challenges, "Computers in Industry" 2012, vol. 63 (4), p. 278-288. 
„może upaść na stopę” i zaspokaja określone potrzeby klienta. Pod pojęciem usługi rozumieją czynność (działanie, praca) wykonaną na rzecz drugiego podmiotu lub osoby, posiadającą wartość ekonomiczną i najczęściej podejmowaną w celach czysto komercyjnych. Może ona być wykonana przez człowieka lub przez maszynę. Definicja systemu przyjęta przez autorów to ,zbiór elementów wraz z łączącymi je relacjami”. Z tych podstawowych terminów składa się pojęcie systemu produktowo-usługowego, czyli, zdaniem Goedkoopa i pozostałych autorów, zbywalny zbiór produktów i usług zdolnych zaspokoić łącznie określone potrzeby użytkownika. System taki może być dostarczany przez przedsiębiorstwo lub grupę współpracujących przedsiębiorstw (alians); dotyczyć może jednego lub kilku produktów z dodatkowymi usługami, lub odwrotnie (jednej lub kilku usług $\mathrm{z}$ dodatkowymi produktami), a komponenty materialne i niematerialne systemu są równie istotne w procesie jego dostarczania ${ }^{15}$.

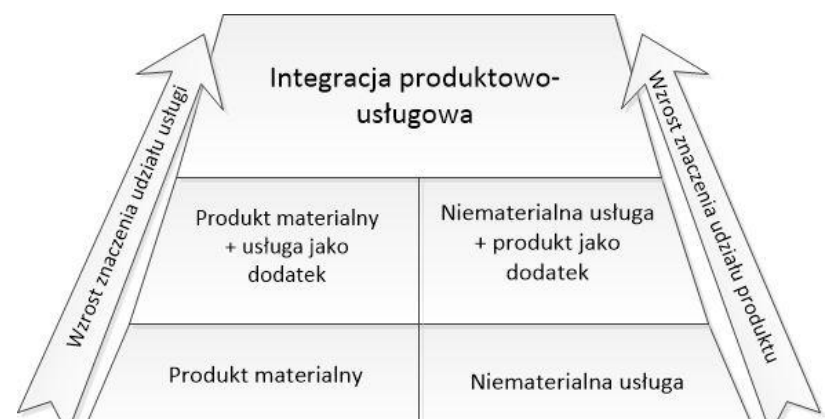

Rys. 1. Ewolucja koncepcji łączenia produktów z usługami

Źródło: opracowanie własne na podstawie: T.S. Baines i in., The state-of-the-art in Product Service Systems, "Journal of Engineering Manufacture" 2007, IMechE, Part B: J. Engineering Manufacture, vol. 221, p. 1543-1552; J. Janczewski, Systemy produktowo-ustugowe w transporcie - wybrane przyktady, "Zarządzanie Innowacyjne w Gospodarce i Biznesie" 2014, nr 1 (18), s. 51-61.

Większość definicji proponowanych w literaturze ${ }^{16}$ podkreśla aspekty związane z poprawą pozycji konkurencyjnej na rynku i podniesieniem satysfakcji klientów oraz możliwościami ekonomicznymi, jakie daje wprowadzenie systemowych ofert w strategię przedsiębiorstwa. Zazwyczaj również wspomina się o ekologicznych plusach takiej zmiany i jej zgodności z nurtem propagującym zrównoważony rozwój. Warto jednak zwrócić uwagę, na te definicje, które wskazują dość istotną różnicę w ujęciu terminu. Manzini i Vezzoli (2003 r.) podkreślają, iż integracja produktowo-usługowa jest efektem „innowacyjnej

15 M.J. Goedkoop, C.J.G. van Halen, H. R.M. te Riele, P.J.M. Rommens, Product Service systems, Ecological and economic Basics, 1999, http://teclim.ufba.br/jsf/indicadores/holan\%20Product\%20Service\%20Systems\%20main\%20report.pdf (dostęp: 28.04.2016 r.)

16 Patrz zestawienie dokonane przez: A. Tukker, Product services for a resource-efficient..., p. 76-91; T.S. Baines i in. The state-of-the-art..., vol. 221, p. 1543-1552; J. Kozłowska, The concept of products and services integration-analysis of scientific publication, "Business Management and Edutation" 2016, Vol. 14 (1), p. 89-102. 
strategii polegającej na przesunięciu koncentracji (uwagi) biznesowej z produktu fizycznego (oraz sprzedaży) na system produktów i usług (oraz sprzedaż), które łącznie zdołają zaspokoić określone wymagania klienta" ${ }^{17}$, zatem akcentują działania, jakie należy podjąć planując rozszerzenie dotychczasowej oferty przedsiębiorstwa. Ostaeyen (w roku 2014) proponuje jedną z prostszych definicji systemów produktowo-usługowych, czyli: „PSS to oferta integrująca produkty i usługi, w której bazą mechanizmu osiągania zysków jest dostępność, użyteczność/użytkowanie lub rezultat"18. Jest to jedyna definicja, która ujmuje mechanizm uzyskania przychodów w procesie dostarczania kompleksowych rozwiązań typu PSS. Tukker przytacza również definicję zaproponowaną przez zespół badaczy chińskich (Zhang i inni, w 2012 r.), według których Zintegrowany System Produktowo-Usługowy (iPSS) to „systematyczny zestaw, w którym niematerialne usługi załączone są do materialnego produktu $\mathrm{w}$ celu dopełnienia rozmaitych działań przemysłowych w ciągu całego cyklu życia produktu" ${ }^{\prime 19}$. W ten sposób podkreślony został dostęp producenta do produktu w całym cyklu życia, dzięki czemu konserwacja i utrzymanie, monitorowanie sprawności, wprowadzanie innowacji i udoskonaleń, czy utylizacja, są pod jego kontrolą.

Różnorodność i mnogość pojawiających się wciąż definicji stanowi potwierdzenie świeżości i nowości tej dziedziny w nauce, co zachęca kolejnych badaczy do podjęcia rozważań zarówno w tematach już dyskutowanych, jak i dotychczas pomijanych.

\section{WĄTKI BADAWCZE POWIĄZANE Z TEMATYKĄ PSS}

W literaturze tematu, wśród terminów, które można bezpośrednio powiązać z obszarem integracji produktowo-usługowej lub które opierają się na tych samych podstawowych założeniach wymienić można: product-service systems ${ }^{20}$, industrial product-service system $^{21}$, services in product-oriented comapnies ${ }^{22}$, service-oriented products ${ }^{23}$, hybryd offerings $^{24}$, servicization ${ }^{25}$, product-service offerings ${ }^{26}$, integrated solutions ${ }^{27}$, pro-

${ }^{17}$ E. Manzini, C. Vezzoli, A strategic design approach to develop sustainable product service systems:examples taken from the 'envirnmentally friendly innovation' Italian prize, "Journal of Cleaner Production" 2003, Vol. 11(8), p. 851-857.

18 J. van Ostaeyen, Analysis of the business potential of product-service systems for investment goods. Rozprawa doktorska, Katholieke Universiteit Leuven 2014. https://lirias.kuleuven.be/ bitstream/123456789/429733/1/thesis.pdf (dostęp: 11.04.2016 r.)

19 A. Tukker, Product services for a resource-efficient...

${ }^{20}$ M.J. Goedkoop, C.J.G. van Halen, H.R.M. te Riele, P.J.M. Rommens, Product Service sys-

tems...; O. Mont, Clarifying the concept...; A. Tukker, Eight types of product-service system: _eight ways to sustainability? experiences from SusProNet, "Business Strategy and the Environment" 2004, Vol. 13 (4), p. 246-260.

${ }^{\overline{21}}$ H. Meier, R. Roy, G. Selinger, Industrial Product-Service Systems - IPS2, "CIRP Annals - Manufacturing Technology" 2010, Vol. 58, p. 607-627.

${ }^{22}$ H. Gebauer, S. Joncourt, C. Saul, Services in product-oriented companies: past, present and future, "Universi Business Review" 2016, Vol. 1, p. 32-53.

${ }_{23}$ A. Tan, Service-oriented product development strategies. Rozprawa doktorska. Technical University of Denmark, 2010, dokument elektroniczny, http://orbit.dtu.dk/fedora/objects/orbit:82986/ datastreams/file 5177222/content (dostęp: 18.05.2016 r.).

${ }^{24}$ W. Ulaga, W.J. Reinartz, Hybrid Offerings: How Manufacturing Firms Combine Goods and Services Successfully, “Journal of Marketing” 2011, Vol. 75 (6), p. 5-23.

\begin{tabular}{|c|}
\hline $\begin{array}{l}\text { Sformatowano: Kolor czcionki: Tekst } \\
1\end{array}$ \\
\hline $\begin{array}{l}\text { Sformatowano: Angielski (Stany } \\
\text { Zjednoczone) }\end{array}$ \\
\hline $\begin{array}{l}\text { Sformatowano: Bez podkreślenia, } \\
\text { Kolor czcionki: Tekst } 1\end{array}$ \\
\hline Usunięto: - \\
\hline $\begin{array}{l}\text { Sformatowano: Bez podkreślenia, } \\
\text { Angielski (Stany Zjednoczone) }\end{array}$ \\
\hline $\begin{array}{l}\text { Sformatowano: Angielski (Stany } \\
\text { Zjednoczone) }\end{array}$ \\
\hline Usunięto: \\
\hline
\end{tabular}


duct/service solutions ${ }^{28}$; ale również, według Tan'a ${ }^{29}:$ eco-efficient services, service engineering, functional sales, functional products i life cycle management.

$\mathrm{Na}$ rys, 2 przedstawiono fragment mapy gęstości, która obrazuje wyniki analizy tekstowej przeprowadzonej na rezultatach przeszukania repozytorium prac naukowo_badawczych Scopus. Analizy abstraktów i tytułów publikacji z zakresu PSS pod kątem pojawiających się najczęściej terminów i słów oraz wizualizacji wyników dokonano $\mathrm{z}$ wykorzystaniem narzędzia VOSviewer. Baza Scopus, według wielu autorów ${ }^{30}$ uznana została za jedną z większych kolekcji opracowań naukowych z różnych dziedzin (osiągnięto wynik ok. 50 mln dokumentów przy prostym wyszukiwaniu określnika angielskiego „the”, czyli takiego, który zawiera prawdopodobnie każdy tytuł lub streszczenie pracy w języku angielskim - stan na dzień 05.05.2016 r.). W najciemniejszych polach mapy znajdują się te słowa, które najczęściej pojawiały się w analizowanych dokumentach (ponad 1100 publikacji otrzymane w wyniku wyszukiwania fraz: „product-service system”, „product service integration”, ,integrated product service”, ,product servicization”, ,product service offerings"). Jako próg minimalny dla częstości wystąpień przyjęto liczbę 20 , próg ten osiągnęło ponad 400 słów. Rozmiar czcionki informuje o wyniku częstości pojawiania się (im większa czcionka, tym częściej słowo występowało w tytule lub abstrakcie analizowanych dokumentów). Odległość zaś wskazuje na współwystępowanie terminów - im bliżej na mapie znajdują się słowa, tym częściej występowały one w jednym opracowaniu. Nasycenie koloru, na tle którego widać dany termin, podobnie jak w kartografii, informuje o wysokości wyniku występowania słów (najciemniejsze pola obejmują terminy najczęściej się pojawiające, nieco jaśniejsze - wynik pośredni, najjaśniejsze najniższy). Dokładniejsza analiza mapy pozwala wskazać najczęściej podejmowane w literaturze akademickiej tematy związane z integracją produktowo-usługową. Stosunkowo czesto podejmowanym tematem są metody stosowane w zakresie systemów produktowo-usługowych (methodology oraz pss - duża czcionka, niewielka odległość), czy też opracowywanie rozwiązań systemowych_pss oraz development process $\mathrm{w}$ bardzo bliskiej odległości). Z mapy wynika również, iż często dyskutowanym aspektem jest pespektywa klienta i jego potrzeby, gdyż te dwa terminy znajdują się w bezpośrednim sąsiedztwie na polu czerwonym. Podejmowane badania dość często dotyczyły też przeglądu zagadnień związanych z PSS (literature review) lub też znaczenia omawianych kwestii czy metod. $\mathrm{W}$ ten sposób można zidentyfikować niektóre wątki najczęściej poddawane dyskusji naukowej.

25 A. Neely, The Serivitization of Manufacturing: An analysis of Global Trends, 2007, dokument elekroniczny, http://202.120.224.199/picture/article/110/00e3fddc-df0b-4e8b-96b6-89db9d41a 29d/8eb0e8f8-9868-479d-a425-cde8d5ca218d.pdf (dostęp: 08.05.2016 r.).

${ }^{26}$ P. Gaiardelli, B. Resta, V. Martinez i in., A classification model for product-service offerings, "Journal of Cleaner Production" 2014, Vol. 66, p. 507-519.

27 R. Shelton, Integrating product and services innovation, "Research - Technology Management" 2009, Vol. 52 (3), p. 38-44.

${ }^{28}$ R. More, Marketing High Profit Product/Service Customer Solutions, Farnham, Burlington: Gower publishing 2013.

$\overline{29}$ A. Tan, Service-oriented product..., s. 33.

30 Zob. A. Tukker, Eight types of product-service system: eight ways to sustainability?...; M. Qu, $\mathrm{S}$. Yu, D. Chen, J. Czu, B. Tian, State-of-the-art of design, evaluation, and operation methodologies in product service systems, "Computers in Industry" 2016, Vol. 77, p. 1-14. 


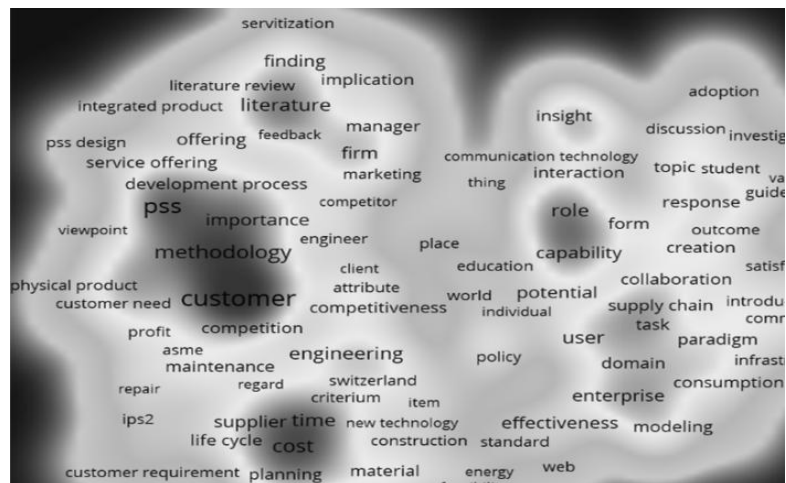

Rys. 2. Fragment wizualizacji mapy gęstości odzwierciedlającej częstość pojawiania się terminów/słów w publikacjach naukowych na bazie wyników przeszukiwania repozytorium Scopus (stan na dzień: 04.04.2016 r.)

Źródło: opracowanie własne z wykorzystaniem aplikacji VOSviewer.

Na rys. 3 przedstawiono 10 czasopism z największą liczbą publikacji w tematyce PSS, co pozwala zauważyć, że najczęściej badano problemy integracji produktowo-usługowej w obszarze przemysłu i produkcji (pięć z 10 tytułów czasopism ma słowo „manufacturing” bądź „production” w tytule). Obrazuje to potrzebę poszukiwania i opracowywania nowych rozwiązań dla kompleksowych rozwiązań systemowych w sektorze wytwórczym. Wątek ten jest tak istotny w badaniach nad integracją produktowo-usługową, iż zdefiniowano rozwiązanie systemowe $\mathrm{w}$ przemyśle jako industrial product-service system i stanowi on dość intensywnie dyskutowany obszar badawczy.

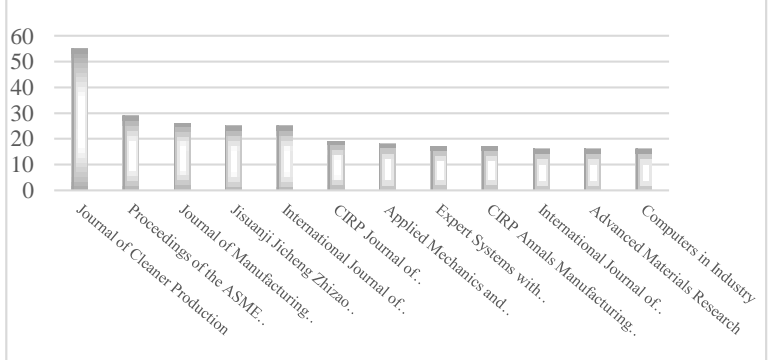

Rys. 3. Czasopisma z największą liczbą publikacji w latach 1980-2015 ujętych w bazie Scopus Źródło: opracowanie własne.

Podejmowane w ciągu ostatnich kilkunastu lat wątki badawcze i liczne analizy stu| diów przypadków pozwoliły rozwinąć stan wiedzy związany z integracją produktowo- 
_usługowej w zakresie klasyfikacji rozwiązań systemowych (przez niektórych autorów uznawane za modele biznesowe integracji produktowo-usługowej ${ }^{31}$ ). Klasyfikację wszystkich możliwych typów rozwiązań PSS przedstawiono na rys. 4. Podział ten, w wersji podstawowej (czyli trzy kategorie główne) jest już dość dobrze ugruntowany w literaturze i w badaniach. Tukker w 2004 roku, w ramach trzech głównych typów, dokonał identyfikacji 8 podkategorii integracji produktowo-usługowej (rys. 4).

Sformatowano: Czcionka: 20 pt

\begin{tabular}{|c|c|c|}
\hline \multirow{3}{*}{$\begin{array}{c}\text { Wartość } \\
\text { uzyskana } \\
\text { ze } \\
\text { sprzedaży } \\
\text { produktu }\end{array}$} & Integracja produktowo-usługowa & \multirow{3}{*}{$\begin{array}{l}\text { Wartość } \\
\text { uzyskana ze } \\
\text { świadczenia } \\
\text { usługi }\end{array}$} \\
\hline & Usługa (część niematerialna oferty) & \\
\hline & Produkt (materialna część oferty) & \\
\hline
\end{tabular}

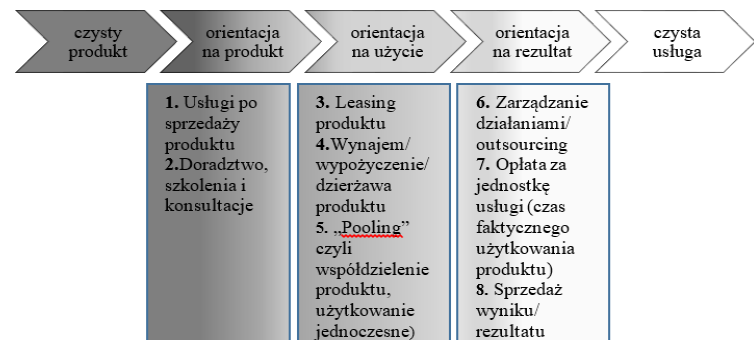

Rys. 4. Typy integracji produktowo-usługowej

Źródło: opracowanie własne na podstawie: A. Tukker, Eight types..., p. 246-260.

\section{STAN OBECNY I SYGNALIZOWANE WYZWANIA NA PRZYSZLOŚĆ}

Aktualność omawianej tematyki odzwierciedla liczba publikacji naukowych związanych z obszarem integracji produktowo-usługowej w ostatnich latach. Na rys 5 przedstawiono kształtowanie się liczby opracowań naukowych w latach od 1980 r. (pierwsze artykuły pojawiły się po tej dacie) do 2015 r. Przeszukania dokonano w bazie Scopus i te wyniki zaprezentowano na wykresie, jakkolwiek autorka analizowała zawartość kilku innych baz (Web of Science, Science Direct, Springer) uzyskując podobne rezultaty, które wraz z dokładną analiza bibliometryczną zagadnienia PSS zawarte zostały w innej publi$\mathrm{kacji}^{32}$. Według wyników przedstawionych na wykresie (rys. 5) od roku 2009 liczba publikacji na temat PSS rocznie przekracza 100.

${ }^{31}$ W. Reim, V. Parida, D. Örtqvist, Product-Service Systems (PSS) business models and tactics a systematic literature review, "Journal of Cleaner Production" 2015, Vol. 97, p. 61-75.

32 Zob. J. Kozłowska, The concept of products... 


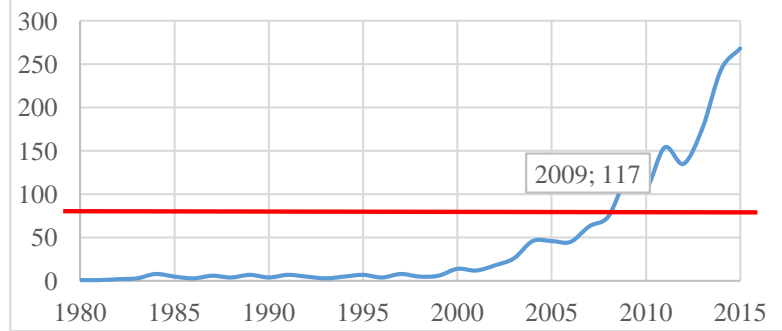

Rys. 5. Liczba publikacji związanych w product-service systems w latach 1980-2015

Źródło: opracowanie własne na podstawie wyników wyszukiwania w bazie Scopus.

Analiza wykresu kształtowania się liczby publikacji na temat integracji produktowousługowej pozwala ocenić, iż ten obszar naukowy jest wciąż w fazie rozwoju - liczba publikacji rośnie w bardzo szybkim tempie i na rok 2015 nie wykazuje jeszcze stabilizacji ani tym bardziej spadku zainteresowania środowiska naukowego tą tematyką.

Przegląd wybranych publikacji z ostatnich 5 lat pozwolił na przedstawienie proponowanych przez autorów problemów badawczych i wyzwań dla nauki. Qu i inni wskazują na potrzebę opracowania dedykowanych metod wizualizacji lub adaptacji metod z innych dziedzin (inżynierii czy zarządzania) w zakresie projektowania systemów produktowousługowych. Uważają również, iż należy skupić się na badaniach ilościowych w zakresie metodologii projektowania, ewaluacji i operacjonalizacji rozwiązań systemowych PSS, które pozwoliłyby obiektywnie ocenić wpływ integracji produktowo-usługowej na gospodarkę, społeczeństwo i środowisko ${ }^{33}$. Tukker z kolei zauważa, że obszar badawczy związany z PSS, mimo dość intensywnego rozwoju, wciąż wykazuje luki w zakresie ontologii, terminologii i konceptualizacji integracji produktowo-usługowej (tu: product-service systems). Metody projektowania, mimo szerokiego wachlarza propozycji $\mathrm{w}$ literaturze, wykazują niski poziom dojrzałości i skupiają się na konceptualizacji i generacji pomysłów, zaś wykazują braki w zakresie narzędzi, które pozwoliłyby zoperacjonalizować projekt wdrożenia rozwiązania w różnych sektorach. Również (nie)korzyści dla biznesu i środowiska pozostają niedostatecznie zbadane. Przeprowadzone badania (zazwyczaj są to studia przypadków) w większości potwierdzają słuszność wprowadzenia rozwiązania klasy PSS w przedsiębiorstwach, jednak nie jest to panaceum na zrównoważony rozwój; w niektórych przypadkach, zwłaszcza w relacjach B2C, nie jest opłacalne ani wskazane | chociażby ze względów ekologicznych (np. z uwagi na szybki rozwój technologiczny i błyskawicznie pojawiające się innowacje, czy też konieczność stosowania skomplikowanych rozwiązań logistycznych, które wpływają niekorzystnie na środowisko naturalne). Tukker również wskazuje na uderzający brak badań ilościowych i danych statystycznych pozwalających analizować korzyści ekonomiczne oraz te wynikające z wprowadzenia różnych modeli integracji produktowo-usługowej na różnych rynkach, które mają wpływ na konkurencyjność i zrównoważony rozwój ${ }^{34}$. Według Gebauera i innych jedną z najbar-

${ }^{33}$ M. Qu, S. Yu, D. Chen, J. Czu, B. Tian, State-of-the-art of design...

${ }^{34}$ A. Tukker, Eight types of product-service system: eight ways to sustainability?... 
dziej istotnych kwestii przy rozszerzaniu oferty przedsiębiorstwa produkcyjnego o usługi jest zrozumienie jej roli w przemyśle, a zatem potrzebne są badania w celu określenia tejże na różnych etapach cyklu życia przemysłu, jak również ocena ich wpływu na wyniki biznesowe osiągane na poszczególnych etapach. Innymi pytaniami wartymi rozważań są, zdaniem autorów: W jaki sposób transformacja $\mathrm{z}$ producenta wyrobów fizycznych w dostawcę usług wpływa na umiejętności przedsiębiorstw w zakresie stosowania innowacji strategicznych? W jaki sposób przedsiębiorstwa wytwórcze w krajach o niskich dochodach stosują modele biznesowe typu PSS $?^{35}$. Gaiardelli i inni zauważają, że minusem proponowanych rozwiązań, w tym ich modelu klasyfikacji ofert produktowo-usługowych, jest założenie, iż dostawca PSS sam świadczy usługi, podczas, gdy w praktyce często są one wykonywane przez inne podmioty partnerskie. Ten aspekt zazwyczaj pomijany jest $\mathrm{w}$ badaniach ${ }^{36}$. Durugbo zaś zaznacza konieczność zbadania znaczenia wprowadzania zintegrowanych ofert systemowych w przemyśle na budowanie krótkoi długoterminowych relacji. A także pytania: jaka jest natura kontraktów wśród firm wytwórczych w zakresie projektowanie i dostarczania rozwiązań PSS? czy relacje z partnerami $\mathrm{w}$ sektorze przemysłu wynikają $\mathrm{z}$ historii doświadczeń czy też może wymagania technologiczne na potrzeby dostarczania rozwiązań kombinowanych determinują nowe relacje, inaczej ukierunkowane, z partnerami o zupełnie innym profilu działania niż dotychczasowi? - pozostają wciąż bez odpowiedzi.

\section{PODSUMOWANIE}

Obszar wiedzy związany z integracją produktów materialnych z usługami jest dość intensywnie dyskutowany w literaturze i rozwija się bardzo dynamicznie w ostatnich latach. Jego narodziny wiążą się ze zmianami zachodzącymi w gospodarce (dematerializowanie ekonomii, serwicyzacja gospodarki, orientacja funkcjonalna gospodarki), zaś potencjał związany z nurtem zrównoważonego rozwoju był główną przesłanką wielu badań naukowych prowadzonych w tym zakresie. Od lat 90 . XX wieku środowisko akademickie nie zdołało wypracować jednej definicji ani dobrać jednoznacznego pojęcia na stosowanie zintegrowanych rozwiązań systemowych $\mathrm{w}$ ofercie przedsiębiorstwa. Jednym $\mathrm{z}$ najczęściej używanych terminów jest system produktowo-usługowy, który określa integrację materialnego produktu z niematerialna usługą w kompleksowy sposób pozwalający zaspokoić określone potrzeby klienta. Zaznacza się przy tym, iż stosowanie tych rozwiązań pozwala ograniczyć szkodliwy wpływ produkcji na środowisko naturalne, poprzez optymalizację jej parametrów, przedłużanie cyklu życia produktów oraz kontrowaną ich utylizację. Ze strony ekonomicznej i marketingowej integracja produktowo-usługowa jest zazwyczaj również korzystną zmianą, gdyż stanowi nowe źródło korzyści finansowych i pozwala nawiązać nowy typ relacji z klientami. Dotychczasowe badania w zakresie integracji produktowo-usługowej dotyczyło wielu różnych aspektów wdrażania i stosowania zintegrowanych ofert produktowo-usługowych. Jednym z problemów, które znalazły swoje rozwiązanie jest typologia integracji produktowo-usługowej. Pomimo rozwoju i postępu stanu wiedzy w omawianym obszarze, wiele pytań wciąż pozostaje bez odpowiedzi, a wiele zagadnień wymaga bardziej szczegółowych badań.

${ }^{35}$ H. Gebauer, S. Joncourt, C. Saul, Services in product-oriented..

${ }^{36}$ P. Gaiardelli, B. Resta, V. Martinez i in., A classification model for product-service... 


\section{LITERATURA}

[1] Baines T.S. i in., The state-of-the-art in Product Service Systems, "Journal of Engineering Manufacture, IMechE, Part B: J. Engineering Manufacture, 2007, Vol. 221, p. 1543-1552.

[2] Brzustewicz P., Systemy produktowo-ustugowe jako sposób realizacji rozwoju zrównoważonego w biznesie, „Marketing i Rynek” 2012, nr 10, s. 23-27.

[3] Cavalieri S., Pezzotta G., Product-Service Systems Engineering:State of the art and research challenges, "Computers in Industry" 2012, Vol. 63 (4), p. 278-288.

[4] Gaiardelli P., Resta B., Martinez V. i in., A classification model for product-service offerings, "Journal of Cleaner Production" 2014, Vol. 66, p. 507-519.

[5] Gebauer H., Joncourt S., Saul C., Services in product-oriented companies: past, present and future, "Universi Business Review" 2016, Vol. 1, p. 32-53.

[6] Goedkoop M.J., van Halen C.J.G., te Riele H.R.M., Rommens P.J.M., Product Service systems, Ecological and economic Basics, 1999, dokument elektroniczny, http://teclim.ufba.br/jsf/indicadores/holan\%20Product $\% 20$ Service $\% 20$ Systems $\% 20$ main \%20report.pdf (dostęp: 28.04.2016 r.).

[7] Janczewski J., Systemy produktowo-ustugowe $w$ transporcie - wybrane przykłady, „Zarządzanie Innowacyjne w Gospodarce i Biznesie” 2014, nr 1 (18), s. 51-61.

[8] Janczewski J., Wynajem jako forma współużytkowania samochodów: wybrane kwestie, „Zarządzanie Innowacyjne w Gospodarce i Biznesie” 2015, nr 2 (21), s. 86-101.

[9] Kozłowska J., Product-Service System in a manufaturing company strategy-s review paper, "Ekonomia i Zarządzanie" 2015, Vol. 7 (2), s. 48-56.

[10] Kozłowska J., The concept of products and services integration-analysis of scientific publication, "Business Management and Edutation" 2016, Vol. 14 (1), p. 89-102.

[11] Kronenberg J.,Bergier T. (red.), Wyzwania zrównoważonego rozwoju w Polsce, Fundacja Sendzimira, Kraków 2010.

[12] Manzini E., Vezzoli C., A strategic design approach to develop sustainable product service systems: examples taken from the 'environmentally friendly innovation' Italian prize, "Journal of Cleaner Production" 2003, Vol. 11 (8), p. 851-857.

[13] Meier H., Roy R., Selinger G., Industrial Product-Service Systems - IPS2, "CIRP Annals Manufacturing Technology" 2010, 58, p. 607-627.

[14] Mont O., Clarifying the concept of product-service system. "Journal of Cleaner Production" 2002, Vol. 10 (3), p. 237-245.

[15] Neely A., The Serivitization of Manufacturing: An analysis of Global Trends, 2007, dokument elekroniczny, http://202.120.224.199/picture/article/110/00e3fddc-df0b-4e8b96b6-89db9d41a29d/8eb0e8f8-9868-479d-a425-cde8d5ca218d.pdf (dostęp: 08.05.2016 r.)

[16] More R., Marketing High Profit Product/Service Customer Solutions, Gower publishing, Farnham, Burlington 2013.

[17] Ostaeyen van J., Analysis of the business potential of product-service systems for investment goods. Rozprawa doktorska, Katholieke Universiteit Leuven, 2014, https:// lirias.kuleuven.be/bitstream/123456789/429733/1/thesis.pdf (dostęp: 11.04.2016 r.).

[18] Qu M., Yu S., Chen D., Czu J., Tian B., State-of-the-art of design, evaluation, and operation methodologies in product service systems, "Computers in Industry" 2016, Vol. 77, p. 1-14.

[19] Shelton R., Integrating product and services innovation, "Research - Technology Management" 2009, Vol. 52 (3), p. 38-44. 
[20] Stahel W.R., The functional economy: cultural and organizational change [w:] The industrial green game: implications for environmental design and management, National Academy Press, Waszyngton 1997.

[21] Szymańska E., Serwicyzacja gospodarki jako źródło jej transformacji, "Optimum. Studia Ekonomiczne" 2015, nr 1 (73), s. 97-109.

[22] Tukker A., Eight types of product-service system: eight ways to sustainability? experiences from SusProNet, "Business Strategy and the Environment" 2004, Vol. 13 (4).

[23] Tukker A., Product services for a resource-efficient and circular economy - a review, "Journal of Cleaner Production" 2015, Vol. 97, p. 76-91.

[24] Tukker A., Tischner U., Product-services as a research field: past, present and future. Reflections from a decade of research, "Journal of Cleaner Production" 2006, Vol. 14 (17), p. 1552-1556.

[25] Tan A., Service-oriented product development strategies. Rozprawa doktorska. Technical University of Denmark, 2010, dokument elektroniczny. http://orbit.dtu.dk/fedora/objects/ orbit:82986/datastreams/file_5177222/content (dostęp: 18.05.2016 r.).

[26] Ulaga W., Reinartz W.J., Hybrid Offerings: How Manufacturing Firms Combine Goods and Services Successfully, "Journal of Marketing" 2011, Vol. 75 (6), p. 5-23.

[27] Vezzoli C., Kohtala C., Srinivasan A., Product-Service System Design for Sustainability. Sheffield: Greenleaf Publishing Limited 2014.

\section{EVOLUTION OF THE CONCEPT OF PRODUCT AND SERVICE INTEGRATION (PRODUCT-SERVICE SYSTEMS)}

Nowadays, the line between manufacturing and the service sector has become blurred, and sometimes imperceptible. Both, service companies as well as manufacturing enterpreneurs, are interested in expanding their offers so that they could meet the needs of its customers more comprehensively. On the other hand, the conditions of intense competition among market players force entrepreneurs to innovate their strategy and enrich offers in order to establish long and positive relationships with customers, partners and suppliers. The concept of integrating products (physical goods) and services, as a system solution offered to customers in the form of a comprehensive offer that is oriented on its functionality or the result, is a relatively new area of research, still hot and eagerly discussed in academic circles around the world. The integrated offering allows to meet these customers' needs, which the product or service alone are not able to meet at a certain level of satisfaction. Introducing services into the activity of the industrial sector companies concurs with the trend of sustainable development through heavy emphasis on the turnover of intangible asset, that is a service. The aim of the article is to review the literature for the development of the concept of a product and service integration (usually referred to in the foreign literature as a productservice system) and the directions of research undertaken in this area. An overview of selected literature allowed to identify research problems and questions, which are challenges for academia for the future.

Keywords: product-service system, servicization, product-service integration, literature review, text mining analysis.

\section{DOI: 10.7862/rz.2017.mmr.6}




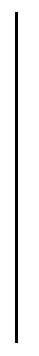

